\title{
Exploring the Relationship Between Corporate Volunteering and Internal Communications in Multinational Organizations
}

Original scientific paper _ DOI 10.22522/cmr20160208 _ received on 4 October 2016 UDK 005.35:334.726 658.3:364.467

........

\section{Alex Malouf}

Procter \& Gamble, Dubai, United Arab Emirates. Email: malouf.ag@pg.com

\section{Marko Selaković}

DOBA Faculty of Applied Business and Social Studies, Maribor, Slovenia.

Email: marko.selakovic@new.doba.rs

\section{Nikolina Ljepava}

American University in the Emirates, Dubai, United Arab Emirates. Email: nikolina.ljepava@aue.ae

(.......

\section{Abstract}

The purpose of this paper is to explore the relationship between internal communications and corporate volunteering in order to better understand how companies promote volunteerism among employees. According to Aguilera et al. (2007), volunteerism can be promoted by directly communicating about such programmes, as well as indirectly communicating to employees on organizational purpose, strategy and values. A survey has been conducted with employees of three multinational companies, and data were analysed to comprehend the relationship between employee understanding of their company's organizational purpose, CSR strategy and employee participation in both structured volunteering programmes and out-of-work volunteering. The authors concluded that management of internal communications has an impact on aligning employees' perception of the company's organizational purpose with its CSR strategy and in prompting them to actively take part in employee volunteering programmes. The research conducted proves the interdependence between internal communications and corporate volunteering: when the internal communications were effective, there were higher volunteering engagement rates and a more positive organizational image. In addition, the research provides an understanding of the state of corporate volunteering and its relationship with internal communications in a country which could be described as an emerging market both from the point-of-view of local approaches to CSR as well as its economic status. Findings have been used to identify how companies can better align their organizational purpose and CSR strategy via internal communications in order to better promote volunteering programmes amongst staff.

Keywords: internal communications, CSR, corporate volunteering, employee engagement 


\section{Introduction}

\subsection{Internal Communications within a Strategic Narrative}

The concept of communications within the setting of an organization was conceived by American writers at the end of the 1940s. Simon (1997) considered communication as the essence of an organization, as part of his treatise on organizational behaviour in the 1940s. The relationship between communications and the organization has since developed; today, the definition of strategic communications focuses on how an organization promotes itself through "intentional activities of its leaders, employees and communications practitioners" (Hallahan et al., 2007, p. 7). Strategic communication provides organizational leaders with the ability to purposefully advance the organization's mission. Corporate social responsibility (CSR) within the context of business practice was a matter of profound academic research, both in terms of a company's responsibilities to society and the relationship between a firm's CSR activities, its profitability and value. CSR has been widely adopted by corporations over the last thirty years (Bies et al., 2007); so has a specific aspect of CSR, that of corporate volunteering (Mirvis, 2012). It has become increasingly common for companies to put in place employee volunteering programmes as part of their CSR strategies. Less attention has been paid, however, to the relationship between internal communications, corporate volunteering and organizational purpose. Pfeffer and Salancik (1978) believe the discipline should be used to control the environment and maintain the autonomy of an organization. In contrast, Quinn (1978) argues that strategy is based on the experience of all employees and as such communication should be also bottom-up to share experiences and prior learnings and thus to support strategy formulation.

Internal communications have a part to play within a strategic communications context. Internal communications, which can be defined as transactions between individuals and groups in organizations at various levels and in different areas of specialization (Frank, Brownell, 1989), facilitate the creation and exchange of messages within a network of interdependent relations (Goldhaber, 1990). Kalla (2005, p. 302) defines internal communications as "all formal and informal communication taking place internally at all levels of an organization", while Orsini (2000, p. 29) defines internal communications as "the full range of ways that people communicate with each other within the organization". 
As the focus is within the organization, the categorization of internal stakeholders is limited. Freeman (1984) listed employees as one of key stakeholder groups in his conceptualization of a modern corporation. Extending Freeman's work, Welch and Jackson (2007) refined the internal stakeholder to three categories: team peer; project peer and line manager relationships. However, as highlighted by Ruck and Trainor (2012), these groups are static and membership is defined by responsibilities and position rather than other associations.

\subsection{Employee Engagement through Internal Communications}

The concept of employee engagement, also referred to as organizational engagement, has a wide variety of definitions which vary based on business, psychology and human resources interpretations (Macey, Schneider, 2008). Employee engagement is primarily defined as both an employee's emotional and intellectual commitment to the organization (Baumruk, 2004) or the effort exhibited by employees for their organizations (Frank et al., 2004). Truss et al. (2006) defined employee engagement in psychological terms as "passion for work", while Kahn (1990, p. 694) defined employee engagement as "the harnessing of organization members' selves to their work roles; in engagement, people employ and express themselves physically, cognitively, and emotionally during role performances”.

The lack of a commonly-agreed definition complicates efforts to implement and measure the concept in the workplace (Ferguson, 2007). The definition of employee engagement given by Robinson et al. (2004, p. IX) states it is "a positive attitude held by the employee towards the organization and its value. An engaged employee is aware of business context, and works with colleagues to improve performance within the job for the benefit of the organization. The organization must work to develop and nurture engagement, which requires a two-way relationship between employer and employee." This definition allows for a distinction between engagement and other concepts such as employee satisfaction, commitment, and organizational behaviour whilst highlighting the duality of employee engagement, as a dialogue between employer and employee.

As organizations strive to create a more efficient and productive workforce, they have focused on employee engagement; increasingly, organizations understand the importance of internal communications in relation to organizational engagement (Argenti, 1996). Studies support 
a positive relationship between effective communication and organizational commitment (DeCotiis, Summer, 1987; Mathieu, Zajac, 1990). Internal communications play an essential role in "building and nourishing employee relations, establishing trust, providing timely and reliable information and thereby contributing to general motivation, particularly in times of change and stress" (Dolphin, 2005, p. 172). Through effective internal communications employees are empowered to become part of the solution and become more committed to the organization (Zajkowska, 2012).

For Bovée and Thill (2008), internal communication is the exchange of information and ideas within an organization. Examining internal communications from an employee's point of view, Truss et al. (2006) argue that the three key factors for employee engagement are having opportunities to feed one's views upwards, feeling well informed about actions within the organization, and believing that one's manager is committed to the organization.

\subsection{The Concept of CSR and Employee Volunteering}

As a concept, CSR has dozens of definitions but academic literature lacks a unifying description (Berete, 2011). Bowen (1953) defines CSR as organizational policies, decision and actions that align with societal goals and values. Davis (1960) and McGuire (1963) defined CSR as actions taken for reasons other than for economic or technical benefits. Jones (1980) refined the concept to include an obligation to groups other than stockholders and insisted CSR's obligations must be broad, voluntary and process-driven.

Today's definitions of CSR are business-oriented (Okoye, 2009) with Fifka's (2009) description of CSR as a company's economic, legal and voluntary responsibilities to participate in the social development of the communities where they operate which are aligned with existing business strategies and product resources being typical of modern academic writing. One frequently-quoted definition which is cited by Aaronson (2003) is that from the NGO Business for Social Responsibility, which is "business decision-making linked to ethical values, compliance with legal requirements, and respect for people, communities, and the environment around the world". Carroll and Shabana (2010) note that no matter the exact characterization of CSR, there are three key thoughts underlining today's concept: ecological; social and economic responsibilities. Research suggests numerous positive 
benefits stemming from CSR for both individuals and organizations, including increased innovation (Hull, Rothenberg, 2008), shareholder value and financial performance (Orlitzky et al., 2003; Waddock, Graves, 1997). Internally, research by Glavas and Piderit (2009) has found that employee engagement is higher for employees who believe they are working for corporations that are good corporate citizens.

Whilst studies suggest a positive correlation between a corporation's economic performance and CSR adoption, the effectiveness of any CSR strategy varies owing to the strategy's operationalization, the stakeholder focus, and methodology employed (Caligiuri et al., 2013); CSR can be perceived to be neutral or negative (McWilliams, Siegel, 2000) and philanthropic activities do not always have a positive relationship for a company's financial performance (Brammer, Millington, 2008).

Skoko and Mihovilović (2014) point out that responsible contemporary management is more aware of the fact that purely profit-oriented business, without care for society, the environment and all stakeholders, cannot be sustainable in the long-term. According to Allen et al. (2011), the definition of corporate volunteerism includes a wide range of corporate sponsored or encouraged activities designed to serve those in need. Corporate volunteering programmes are generally formal, whereby corporations allow employees to volunteer with NGOs during office hours. Bussell and Forbes (2008) describe corporate volunteering as giving one's time, knowledge, or skills as part of a community service, outreach, or social responsibility activity on company time without additional compensation or direct personal remuneration.

Corporate volunteering has grown in popularity since the global economic crisis. CSR has never been as popular among corporations as it is today. Ninety-five percent of the world's 250 largest companies report their CSR activities, and CSR activities are picking up pace in the US, Europe and Asia (KPMG, 2011). Similarly, corporate volunteerism has proved popular with employees, as it enables them to be directly involved in a company's CSR strategy (Mirvis, 2012); employees who engage in corporate volunteering have been found to be more engaged in their workplace (de Gilder et al., 2005). 


\subsection{CSR and Internal Communications}

While CSR and corporate volunteering can prove beneficial to an organization's employee engagement, research by Bhattacharya et al. (2008) has found that employees, including those who want to be engaged in such activities, are often unaware of their employer's CSR policies and activities. In addition, many employees are unable to learn about their company's CSR programmes. In a study conducted by Bhattacharya et al. (2008) within a multinational FMCG, $90 \%$ of respondents agreed it was important for the company to be engaged in CSR; only 50\% agreed that they had a good understanding of the company's CSR commitments.

CSR communication can take place through offline communication channels via print, through in-house media including intranets and brochures, and externally through the internet and CSR reports (Chaudhri, Wang, 2007). The most popular means of communicating CSR to stakeholders include voluntary CSR reporting, media, paid advertising, product-labelling and internal communications (Strandberg, 2009).

Part of the challenge associated with communicating both externally and internally on CSR would appear to be related to the frequency of communications. Companies which overcommunicate risk a negative response from their employees, who may perceive the increase in information on CSR activities as an effort to promote the company (Strandberg, 2009).

\subsection{Employee Voice and CSR Strategy}

As a key stakeholder in any organization, employees impact CSR policy through their perceptions, evaluations, judgment of and reaction to CSR programmes and actions (Rowley, Berman, 2000). This view builds upon the interpretation of CSR offered by Barnett (2007), who notes that CSR is a type of corporate investment which is oriented both towards the improvement of social welfare and of stakeholder relations.

The relationship between employees and CSR strategy, development and execution is complex. Employees can be and often are agents for social change when they influence their corporations to behave in a socially responsible manner (Aguilera et al., 2007). There is debate as to how 
much employees influence or are influenced by the concept and growth of CSR. Aguilera et al. (2007) view employees as an independent variable which has helped to promote CSR within organizations, whereas Peterson (2004) views employees as a stakeholder group that is more influenced by CSR. Barnett (2007) considers that employees are both influencers of and influenced by CSR policy within the context of organizational performance.

The interconnection between CSR, corporate volunteering and employee engagement has also been researched. Multinational companies are "slowly moving from traditional measures, like counting volunteers and hours of service, to adopting more strategic measures built around increasing business or social impacts" (Hills, Mahmud, 2007). Companies are increasingly engaging in employee volunteering as a form of community involvement in response to increased expectations for them to be socially responsible (Muthuri et al., 2009). Bondy et al. (2008) discussed various CSR mechanisms in the context of multinational companies' codes of conduct and recognized certain differences depending upon the region.

In multinational companies, decisions about CSR strategy are often taken by management, who look to maximize benefits for multiple stakeholders (Caligiuri et al., 2013), including shareholders, employees and the community. Corporations which include shareholders as stakeholders are often motivated to undertake CSR not only to do good, but also to increase competitiveness, improve reputation and enhance goodwill to increase financial performance (Aguinis, Glavas, 2012).

However, in contrast to other CSR tools such as financial donations which are typically made by executive management, corporate volunteering may often be led by employees from the bottom-up primarily due to corporate volunteering's differing needs - the long-term success of any corporate volunteering programme is due to the employees themselves (Grant, 2012). One study of American companies suggested that most corporate volunteering programmes are "planned, organized and executed by employees": 62 percent of programmes surveyed were employee-led, of which 15 percent were solely managed by employees (Wainwright, 2005).

Within the context of corporate volunteering, various research suggests that employees make the choice to participate in a corporate volunteering activity for various reasons, including being asked directly (Brudney, Gazley, 2006), feeling pressured or coerced by 
peers/superiors (Houghton et al., 2009), commitment to the organization (Peloza et al., 2009), or receiving paid time off, incentives, donations or other benefits that enhance the desirability of corporate volunteering (Peterson, 2004). Grant (2012) argued that employees who lack enriched job designs, experience stronger motivation to compensate for these job designs through corporate volunteering. However, no research reviewed by the author focuses on employee involvement in corporate volunteering policy development and the benefits of this involvement to employee engagement. Whilst employees in countries such as the US are developing and promoting activities themselves (Wainwright, 2005), there seems to be a disconnection between organizations and employees in terms of choosing volunteering causes that matter to the workforce.

The aim of the present research is to contribute to a better understanding of the link between internal communications and corporate volunteering, to understand why employees volunteer and how corporations can better promote their corporate volunteering programmes through internal communications. As more corporations adopt corporate volunteering as part of a wider CSR strategy, the more important internal communications will become to their success in promoting volunteering among employees.

\subsection{Research Hypotheses and Questions}

Several interest areas and research questions have been highlighted within the present research:

1. To determine the percentage of employees who have volunteered in a volunteering programme, either corporate or non-corporate.

2. What is the influence of internal communications on corporate volunteering within an organization?

3. What employee groups are more likely to take part in a corporate volunteering program?

4. What are barriers and incentives to the promotion of corporate volunteering through internal communications;

5. How corporate volunteering benefits a corporation's organizational engagement efforts? 
Based on the previous research findings, the following research hypotheses are proposed:

- H1: Effective internal communications in multinational organizations operating in the emerging markets result in higher volunteering engagement rates.

- H2: Effective internal communications in multinational organizations operating in the emerging markets result in more positive organizational image.

\section{Methods and Sampling}

The scope of research is focused on a survey of employees in three multinational companies which already have CSR strategies and employee volunteering programmes in place. Each organization has been viewed separately, and within each organization different employee groups were surveyed. Consideration is given to the motivation employees have to volunteer their time and skills outside of corporate employee volunteering programmes and on their own volition.

The questionnaire was hosted online on the Survey Monkey data collection platform and consisted of twenty questions. Prior to sending the survey to chosen companies, a pilot survey was undertaken with five respondents - one from each of the organizations which took part in the survey, one from a government-based organization which promotes volunteering, and one from a non-governmental organization that requests volunteers from the private sector. None from the pilot group took part in the full survey. The first part of the research instrument aimed to provide an understanding of the employee's volunteering habits via dichotomous yes/no response options. The second part aimed to get a sense of the employee's views on corporate volunteering, while the third part of the questionnaire explored the employee's perception of his/her company and how it is being influenced by either corporate volunteering and/or the company's CSR strategy. The fourth section of the questionnaire focused on internal communications practices and its effect on employee volunteering, while the final question was an open-ended question for employees to note their own thoughts and feelings about corporate volunteering in their own company.

Single-stage cluster probability sampling was used for the research (Easterby-Smith et al., 2012) to ensure all employees from each company at a single location were targeted, thereby 
reducing the time required to complete the survey and to reduce any potential sampling error. The clusters for the three companies are heterogeneous; the within-cluster differences are high for each organization while the between-cluster differences are lower, thereby suiting the cluster probability sampling concept (Easterby-Smith et al., 2012). Data analysis was conducted separately for each company, and then compared with data from the other two companies. The open-ended responses were analysed and segmented into categories based on Clampitt's (2009) method for analysing qualitative data collected from surveys.

In total, 90 responses from the employees of three multinational companies, all located in the United Arab Emirates, were received. The majority of respondents (58.8\%) were between 25 and 34 years old, while $24.4 \%$ of the participants were between 35 and 44 years old, while $16.8 \%$ were over 45 years old. Survey respondents were mainly female (62.2\%). Gender trends were apparent and could have been influenced by company type and focus: Company A manufactures and markets goods for the FMCG sector; Company B is financial, and Company $\mathrm{C}$ operates in the energy industry. A complete view of the gender demographics for each company would have helped to put these responses into focus within the context of the research area, to understand if one gender in particular has a preference for corporate volunteering.

The nationality spread was very diverse, and could be taken as typical of the wider nationality representation found in the private sector in the UAE. The most common functions were marketing (25.5\%), procurement and supply chain (23.3\%), finance (14.4\%) and sales (13\%).

\section{Results}

The majority of the employees indicated they had volunteered before. Only $16 \%$ of respondents had not volunteered before. Similarly, when asked if they would volunteer again, the likelihood of future volunteering was high with only $3.3 \%$ of the respondents from Company A indicating that they would not volunteer in the future. Over $50 \%$ of employees from Company A indicated that they did not participate in a company volunteering programme so far, showing either a lack of volunteering opportunities, knowledge of opportunities or a previous lack of engagement. Over $90 \%$ of Company B employees participated in a company volunteering programme while $28 \%$ of the employees from Company $\mathrm{C}$ had not taken part in corporate volunteering, even 
though the participants were recruited from an employee volunteering email list. Responses also indicated strong support across all the companies for corporate volunteering. Overall 98\% of participants responded that they do care if their companies support volunteering efforts; however, only $75 \%$ perceived them as committed to corporate volunteering programmes. The downward trend continues with only $44 \%$ of the participants indicating that they feel empowered to take part in corporate volunteering. Comparative analysis of the responses from different companies indicated that, while Company B's responses to these questions are consistent, there is a gradual decline in agreement for employees of Companies A and C. Further research needs to be undertaken to establish why there is a tapering off when it comes to employee commitment and empowerment in those two companies.

While $64.4 \%$ of respondents believe that the perception of their employer has improved as a result of their corporate volunteering, there is a small percentage (12.2\%) that either disagrees or strongly disagrees with this statement. Compared to this question, ratings are higher for employee perceptions of their company's CSR strategy with $72 \%$ of the respondents agreeing that the perception of their employer has improved due to their company's CSR strategy. The results might suggest either that CSR practices are positively contributing to employee sentiment, or that employees are dissatisfied with their corporate volunteering.

When it comes to management support, around half of the participants (53.3\%) believe that their management supports corporate volunteering, while $18.8 \%$ disagree or strongly disagree. A comparison between responses from different companies indicated that Company $B$ is perceived to provide the most management support (66\%), while Company A provides the least management support to corporate volunteering (46\%). Moreover, less than half of respondents from Company A (47\%) think that the company internal communications promote corporate volunteering, compared to $81 \%$ of the respondents from Company B, and $72 \%$ from Company $\mathrm{C}$ indicating that they are using their internal communications more effectively. The use of internal communications to encourage corporate volunteering seems to be more successful in Companies B (2.19) and C (2.29). Previous responses have alluded to their success in promoting corporate volunteering through internal communications, and there would appear to be a clear link between promoting corporate volunteering through internal communications and successful employee engagement.

Most of the respondents stated that their companies do not reach out to them to ask which 
causes are important and how they can help. It seems that the companies are doing little to engage employees in understanding what matters to them and how to use these insights to shape corporate volunteering strategies. However, most employees do feel that their companies are communicating internally on corporate volunteering successes. Similar to the previous findings, there is less agreement with this statement in Company A, where communications would appear to be weaker than in the other two companies.

Around one fourth of the respondents (24.4\%) responded to the open-ended question, 'is there anything else you'd like to add about corporate volunteering in your organization, with the majority of the responses (12.1\%) coming from the employees from the Company A. Using free text analysis, the most common nouns were volunteering, community, company, employee and programmes.

The responses for Company A are particularly revealing, and demonstrate a demand for an increase in volunteering opportunities at the site that are more inclusive in terms of language and that cater not only to employees but also their families. The issue of a potential lack of awareness is raised, as is the inability to volunteer during the weekday due to a lack of time. There is one request to be part of the group that manages corporate volunteering opportunities, and another which criticizes the company for attempting to turn corporate volunteering into an opportunity to positively brand the company.

Company B's responses are more positive, with several respondents praising the organization and calling for more support for volunteering efforts. Similar to Company A, there is a call for more corporate volunteering opportunities, particularly those which can cater to employee teams rather than individuals. One criticism focuses on the company's priorities, with the respondent questioning the management's commitment to volunteering vis-à-vis sales.

Finally, Company C's respondents highlight a different set of issues, among them the need for clearer communication that is not lost among work correspondence and an urge to clarify what is corporate volunteering vis-à-vis charity. One comment suggests volunteers are usually drawn from the same group, and that others may believe if you are volunteering you are not focused on your work. Another respondent claims corporate volunteering is important for stakeholder needs while another looks introspectively to suggest corporate volunteering helps with personal growth and company networking. 


\section{Conclusions and Recommendations}

This paper contributes to understanding the relationship between corporate volunteering and internal communications. The findings support the hypotheses: when the internal communications were effective, there were higher volunteering engagement rates and a more positive organizational image.

From the survey, the following conclusions are visible: the employees do want to volunteer, they want their companies to provide corporate volunteering programmes, and successful corporate volunteering improves employee perception of their companies. Employees are volunteering of their own volition; they want to do good for their communities, but they do not want to turn a corporate volunteering opportunity into a branding exercise.

The findings suggest that internal communications are crucial to employee engagement - the more that a company informs its employees about programmes and their impact on society, the more engaged the employees feel. Additionally, the interdependence between internal communications and corporate volunteering can be explored in more details in future studies. However, while there is a strong urge to want to volunteer on a company-related programme, further research could look at understanding why more employees are not following this through. Are the employees who want to volunteer on behalf of their company lacking time? Is it a lack of relevant volunteering opportunities? Interviews with the employee and the NGO worker have both noted the difficulty of finding enough corporate volunteers.

The limitations of the study were related to the sample coming only from three multinational corporations, all of which have pre-existing corporate volunteering programmes in place and have internal communications programmes running within their companies. Also the number of employees included or interested in volunteering programme was not equal in each corporation. As a result of this, employee feedback could be skewed and be only indicative regarding the organization as a whole. For this reason, each company's results were analysed independently. 
Based on the study findings, the following recommendations can be made:

1) Companies should engage with their employees; learn of their interests and how they want to engage in corporate volunteering.

2) Companies should allow employees to develop their own corporate volunteering programmes and support this process.

3) Employee engagement should be empowered through management support and policies that allow for volunteering including during work hours.

4) Effective internal communications on the opportunities available through a variety of communications channels should be ensured.

5) Corporate volunteering successes should be communicated internally to promote further employee engagement in such programmes.

\section{Reference List}

- Aaronson, S. A. (2003). Corporate responsibility in the global village: The British role model and the American laggard. Business and Society Review, 108 (3), 309-338.

- Aguilera, R. V., Rupp, D. E., Williams, C. A., Ganapathi, J. (2007). Putting the S back in corporate social responsibility: A multilevel theory of social change in organizations. Academy of Management Review, 32 (3), 836-863.

- Aguinis, H., Glavas, A. (2012). What we know and don’t know about corporate social responsibility: A review and research agenda. Journal of Management, 38 (4), 932-968.

- Allen, K., Galiano, M., Hayes, S. (2011). Global companies volunteering globally: The final report of the Global Corporate Volunteering Research Project. Dulles: International Association for Volunteer Effort.

- Argenti, P. A. (1996). Corporate communication as a discipline. Management Communication Quarterly, 10 (1), 73-97.

- Barnett, M. L. (2007). Stakeholder influence capacity and the variability of financial returns to corporate social responsibility. Academy of Management Review, 32 (3), 794-816.

- Baumruk, R. (2004). The missing link: the role of employee engagement in business success. Workspan, 47 (1), $48-52$.

- Berete, M. (2011). CSR and financial performance: The positive relationship. Germany: LAP Publishing.

- Bhattacharya, C. B., Korschun, D., Sen, S. (2008). Using Corporate Social Responsibility to Win the War for Talent. MIT Sloan Management Review, 49 (2), 37-44.

- Bies, R. J., Bartunek, J. M., Fort, T. L., Zald, M. N. (2007). Corporations as social change agents: Individual, Interpersonal, institutional, and environmental dynamics. Academy of Management Review, 32 (3), 788-793.

- Bondy, K., Matten, D., Moon, J. (2008). Multinational corporation codes of conduct: Governance tools for corporate social responsibility? Corporate Governance: An International Review, 16 (4), 294-311.

- Bovée, C. L., Thill, J. V. (2008). Business Communication Today (9th ed.). New Jersey: Prentice Hall.

- Bowen, H. R. (1953). Social Responsibilities of the Businessman. New York: Harper \& Brothers.

- Brammer, S., Millington, A. (2008). Does it pay to be Different? An Analysis of the Relationship between Corporate Social and Financial Performance. Strategic Management Journal, 29 (12), 1325-1343. 
- Brudney, J. L., Gazley, B. (2006). Moving ahead or falling behind? Volunteer promotion and data collection. Nonprofit Management and Leadership, 16 (3), 259-276.

- Bussell, H., Forbes, D. (2008). How UK universities engage with their local communities: A study of employer supported volunteering. International Journal of Nonprofit and Voluntary Sector Marketing, 13 (4), 363-378.

- Caligiuri, P. M., Mencin, A., Jiang, K. (2013). Win-Win-Win: The Influence of Company-Sponsored Volunteerism Programs on Employees, NGOs, and Business Units. Personnel Psychology, 66, 825-860.

- Carroll, A. B., Shabana, K. M. (2010). The business case for corporate social responsibility: A review of concepts, research and practice. International Journal of Management Reviews, 12 (1), 85-105.

- Chaudhri, V., Wang, J. (2007). Communicating corporate social responsibility on the Internet: A case study of the top 100 IT companies in India. Management Communication Quarterly, 21 (2), 232-247.

- Clampitt, P. G. (2009). The questionnaire approach. In: Hargie, O., Tourish, D. (Eds.), Auditing Organizational Communication (pp. 55-77). London: Routledge.

- Davis, K. (1960). Can Business Afford to Ignore Social Responsibilities? California Management Review, 11 (3), $70-76$.

- DeCotiis, T. A., Summers, T. P. (1987). A path analysis of a model of the antecedents and consequences of organisational commitment. Human Relations, 40, 445-470.

- de Gilder, D., Schuyt, T. N. M., Breedijk, M. (2005). Effects of an Employee Volunteering Program on the Work Force: The ABN-AMRO Case. Journal of Business Ethics, 61 (2), 143-152.

- Dolphin, R. A. (2005). Internal communications: today’s strategic imperative. Journal of Marketing Communications, 11 (3), $171-190$

- Easterby-Smith, M., Thorpe, R., Jackson, P. (2012). Management Research (4th ed). London: Sage Publications.

- Ferguson, A. (2007). Employee engagement: Does it exist, and if so, how does it relate to performance, other constructs and individual differences? Sydney: Macquarie University.

- Fifka, M. (2009). Towards a more business-oriented definition of corporate social responsibility: discussing the core controversies of a well-established concept. Journal of Service Science and Management, 2 (4), 312-321.

- Frank, A., Brownell, J. (1989). Organizational communication and behavior: communicating to improve performance (2+2=5). New York: Holt, Rinehart and Winston.

- Frank, F. D., Finnegan, R. P., Taylor, C. R. (2004). The race for talent: retaining and engaging workers in the 21st century. Human Resource Planning, 27 (3), 12-25.

- Freeman, R. E. (1984). Strategic Management: A Stakeholder Approach. Boston: Pitman.

- Glavas, A., Piderit, S. K. (2009). How does doing good matter? Effects of corporate citizenship on employees. Journal of Corporate Citizenship, 36, 51-70.

- Goldhaber, G. M. (1990). Organizational Communication (5 $5^{\text {th }}$ ed). Dubuque, IA: Brown.

- Grant, A. M. (2012). Giving time, time after time: Work design and sustained employee participation in corporate volunteering. Academy of Management Review, 37 (4), 589-615.

- Hallahan, K., Holtzhausen, D., van Ruler, B., Vercic, D., Sriramesh, K. (2007). Defining strategic communication. International Journal of Strategic Communication, 1 (1), 3-35.

- Hills, G., Mahmud, A. (2007). Volunteering for impact: Best practices in international corporate volunteering. FSG Social Impact Advisors. Retrieved from: https://www.brookings.edu/wp-content/uploads/2016/06/Volunteering_for_Impact.pdf. December 05, 2016.

- Houghton, S. M., Gabel, J. T. A., Williams, D. A. (2009). Connecting the two faces of CSR: Does employee volunteerism improve compliance? Journal of Business Ethics, 87 (4), 477-494.

- Hull, C. E., Rothenberg, S. (2008). Firm performance: The interactions of corporate social performance with innovation and industry differentiation. Strategic Management Journal, 29, 781-789.

- Jones, T. M. (1980). Corporate Social Responsibility, revisited, redefined. California Management Review, 22 (3), 59-67.

- Kahn, W. A. (1990). Psychological conditions of personal engagement and disengagement at work. Academy of Management Journal, 33 (4), 692-724.

- Kalla, H. K. (2005). Integrated internal communications: a multidisciplinary perspective. Corporate Communications: An International Journal, 10 (4), 302-314.

- KPMG (2011). KPMG international survey of corporate responsibility reporting. Amsterdam: KPMG International. 
- Macey, W. H., Schneider, B. (2008). The meaning of employee engagement. Industrial and Organisational Psychology. 1 (1), 3-30.

- Mathieu, J., Zajac, D. (1990). A review of meta-analysis of the antecedents, correlates and consequences of organizational commitment. Psychological Bulletin, 108 (2), 171-194.

- McCrindle, M. (2006). New generations at work: Attracting, recruiting, retaining Generation Y. Australia: Mccrindle Research.

- McGuire, J. W. (1963). Business and Society. New York: McGraw-Hill.

- McWilliams, A., Siegel, D. (2000). Corporate social responsibility and financial performance: Correlation or misspecification? Strategic Management Journal, 21 (5), 603-609.

- Mirvis, P. (2012). Employee Engagement and CSR: Transactional, Relational, and Developmental Approaches. California Management Review, 54 (4), 93-117.

- Muthuri, J. N., Matten, D., Moon, J. (2009). Employee volunteering and social capital: Contributions to corporate social responsibility. British Journal of Management, 20 (1), 75-89.

- Okoye, A. (2009). Theorising corporate social responsibility as an essentially contested concept: Is a definition necessary? Journal of Business Ethics, 89 (4), 613-627.

- Orlitzky, M., Schmidt, F. L., Rynes, S. L. (2003). Corporate social and financial performance: A meta-analysis. Organization Studies, 24 (3), 403-441.

- Orsini, B. (2000). Improving Internal Communications. Internal Auditor, 57 (6), 28-34.

- Peloza, J., Hudson, S., Hassay, D. N. (2009). The marketing of employee volunteerism. Journal of Business Ethics, 85 (2), $371-386$.

- Peterson, D. K. (2004). Recruitment strategies for encouraging participation in corporate volunteer programs. Journal of Business Ethics, 49 (4), 371-386.

- Pfeffer, J., Salancik, G. (1978). The External Control of Organizations: A Resource Dependence Perspective. New York: Harper and Row.

- Quinn, J. B. (1978). Strategic change: Logical incrementalism. Sloan Management Review, 20 (1), 7-21.

- Robinson, D., Perryman, S., Hayday, S. (2004). The Drivers of Employee Engagement. Brighton: Institute for Employment Studies.

- Rowley, T., Berman, S. (2000). A brand new brand of corporate social performance'. Business and Society, 39 (4), $397-418$.

- Ruck, K., Trainor, S. (2012). Developing Internal Communication Practice That Supports Employee Engagement. Maidstone: PR Academy.

- Simon, H. A. (1997). Administrative Behavior: A Study of Decision-Making Processes in Administrative Organizations (4th ed). New York: The Free Press.

- Skoko, B., Mihovilović, M. (2014). Odnosi s javnošću u funkciji društveno odgovornog poslovanja. Praktični menadžment, stručni časopis za teoriju i praksu menadžmenta, 5 (1), 84-91.

- Strandberg, C. (2009). Using Corporate Social Responsibility to Attract, Motivate and Retain Human Resources (Master's thesis). Retrieved from: http://epubl.ltu.se/1402-1552/2009/007/LTU-DUPP-09007-SE.pdf. July 15, 2016.

- Truss, C., Soane, E., Edwards, C., Wisdom, K., Croll, A., Burnett, J. (2006). Working Life: Employee Attitudes and Engagement. London: CIPD.

- Waddock, S. A., Graves, S. B. (1997). The corporate social performance-financial performance link. Strategic Management Journal, 18, 303-319.

- Wainwright, C. (2005). Building the case for corporate volunteering. Business Community Intelligence, July. Retrieved from: www.ourcommunity.com.au/files/bci_firstedition.pdf. March 11, 2014.

- Welch, M., Jackson, P. (2007). Rethinking internal communication: a stakeholder approach. Corporate Communication: An International Journal, 12 (2), 177-196.

- Zajkowska, M. (2012). Employee engagement: How to improve it through internal communication. Human Resources Management \& Ergonomics, 6 (1), 104-117. 


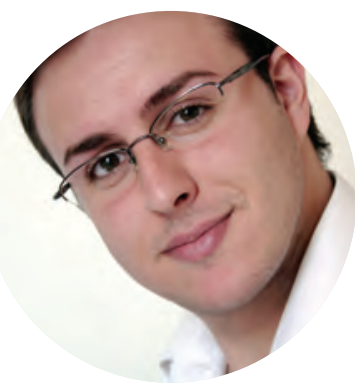

\section{Alex Malouf}

Alex Malouf is a marketing communications executive who has spent the last 14 years in the Middle East and has lived across the region - in Saudi Arabia, Bahrain, Lebanon, Jordan, Syria and the United Arab Emirates. Named as the first Communications Innovator in the MENA region by the Holmes Report, Alex holds a regional corporate communications position for a toptier FMCG based in the UAE. Alex serves on a number of not-for-profit boards, including the Middle East Public Relations Association, the International Association of Business Communicators EMENA Region and the Marketing Society as part of his efforts to promote the marcomms industry across the region.

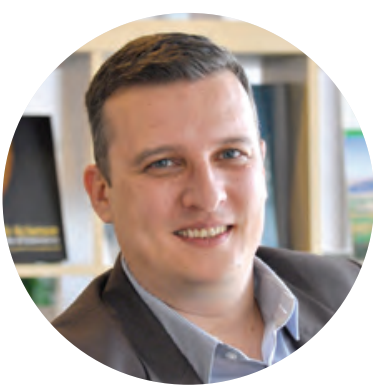

\section{Marko Selaković Nikolina Ljepava}

Marko Selaković is an award-winning communications professional with more than 15 years of toplevel European experience. He is Vice-President of the Board of the International Association of Business Communicators GCC Chapter and held the executive position of Continuing Education \& Training Supervisor at the American University in the Emirates. His portfolio includes C-level advisory and consultancy for Governments, multinational systems and international organizations. Currently, Marko is enrolled in the Master of Business Sciences study programme at the DOBA Faculty of Applied Business and Social Studies, Maribor, Slovenia. Marko is specialized in strategic communications, stakeholder and relationship management and crisis communications.

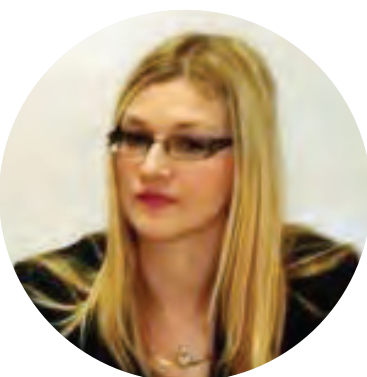

Nikolina Ljepava is an Assistant Professor of Marketing at the American University in the Emirates and Coordinator of E-commerce and Marketing Specialization. She is a practice-oriented academic with more than ten years of international industry and consulting experience in North America, Europe and Asia, in the areas of marketing research, evaluation and assessment and online communications. She holds $\mathrm{PhD}$ from the University of Belgrade, two Master's degrees: in E-business and Social Data Analysis, and a degree in Psychology from the University of Windsor, Canada. Dr. Nikolina's research interests are related to the behavioural studies, cyberpsychology, digital marketing and research methods. 